\title{
Effectiveness of Intradialytic Exercise and Foot Hand Massage On Physiological Response of Blood Pressure
}

\author{
Awan Hariyanto ${ }^{1)}$, Mimik Christiani ${ }^{2)}$ \\ awanhariyanto179@gmail.com
}

\begin{abstract}
Background: End-stage acute and chronic kidney disease requires hemodialysis as an option for treating kidney failure. Hemodialysis patients are reported to experience depression and anxiety affecting blood pressure. Controlling blood pressure during hemodialysis is an important factor in supporting the success of hemodialysis treatment. Interventions that can be given to support anxiety management to have stable blood pressure in hemodialysis renal failure patients were intradialityc exercise and foot hand massage.

Method : The research design used was pre-experimental in the form of one-group pre-post test design. The sampling technique used purposive sampling with a sample size of 20 respondents. Data analysis for data normality used shaphiro-whilk, for general data univariately used frequency distribution tables, while bivariate analysis in paired groups used the Wilcoxon statistical test with a significance level of $\leq$ 0.05 .

Result: The treatment of intradialityc exercise and foot hand massage had an effective effect on the physiological response to the anxiety in patients of renal failure with hemodialysis, including $p$ value: systole blood pressure 0.003 , diastole 0.015 . Intradialytic exercise and foot hand massage given to patients of renal failure under hemodialysis treatment had an effective effect on the physiological response to the anxiety of systole and diastolic blood pressure.

Conclusion : Intradialytic exercise and foot hand massage had an effective effect on stabilizing blood pressure and were recommended to be used as a non-pharmacological nursing intervention for the management of anxiety in patients of renal failure under hemodialysis treatment.
\end{abstract}

Key Words : Intradialytic exercise; foot hand massage; blood pressure

1,2) Department of Nursing Poltekes Kemenkes Malang Prodi Keperawatan Trenggalek, Indonesia J. Dr. Sutomo No.5 Tamanan, Dobangsan Ngantru, Trenggalek, Jawa Timur, Indonesia

Background. Hemodialysis patients are reported to experience depression and anxiety which affect blood pressure. Controlling blood pressure during hemodialysis is an important factor in supporting hemodialysis itself (Tchape, 2018). In a study of 90 patients undergoing hemodialysis, $40.8 \%$ of them experienced depression and $39.6 \%$ experienced anxiety (Semaan, Noureddine, Farhood, 2018). Hospital hemodialysis room medical record data. Dr. Soedomo Trenggalek obtained from the initial survey, the average monthly visits of patients with renal failure who did hemodialysis were 60 patients and $20 \%$ of them were patients with renal failure with hypertension.

In patients who are hemodialized, the procedure takes a long time to allow saturation during intradialysis which can affect the patient's psychology, namely anxiety.
According to (Keliat, 2016) anxiety can affect physiological responses in individuals, including the cardiovascular, respiratory, gastrointestinal, neuromuscular, urinary tract and skin systems.

The results of research conducted by Musavian (2018) stated that intradialityc exercise has a positive role in blood pressure and can reduce serum phosphorus and potassium levels in intradialytic patients. intervention with actions such as relaxation such as massage can reduce anxiety (Melo et all 2018). Interventions that can be given to support anxiety management so that blood pressure is stable in hemodialysis renal failure patients, one of which is intradiality exercise and foot hand massage.

Methods. The research design used preexperimental in the form of one-group pre-post test design. The purpose of this study was to 
determine the difference in effectiveness between before and after treatment of intradialityc exercise and foot hand massage on the physiological response to anxiety of systolic blood pressure and diastole in renal failure patients undergoing hemodialysis. .

The population in this study were all adult patients who experienced kidney failure and underwent hemodialysis in the hemodialysis room of the RSUD. Dr. Soedomo Trenggalek. The sampling technique used in this study was purposive sampling. The independent variables in this study were: intradialityc exercise and foot hand massage and the dependent variable in this study was the physiological response to systolic and diastolic blood pressure. Data processing and data analysis using computer program. Univariate analysis with frequency distribution data, bivariate analysis using the Wilcoxon test with the Shaphiro-Whilk normality test. This study has met the ethical requirements and has obtained permission from the ethical clearance of the ethical clearance of the Ethics Commission of the Health Ministry of Health Malang

Result and Discussion. Intradialytic exercise and foot hand massage given to renal failure patients undergoing hemodialysis have an effective effect on the physiological response of anxiety to systolic and diastolic blood pressure, with a $p$-value $<0.005$

Table 1. Distribution of systolic blood pressure before and after intradialityc exercise and foot hand massage

\begin{tabular}{lcccc}
\hline Variabel & $\begin{array}{c}\text { Mea } \\
\boldsymbol{n}\end{array}$ & SD & $\begin{array}{c}\text { Medi } \\
\text { an }\end{array}$ & Min-max \\
\hline Pre & 173 & 18.382 & 170 & $150-210$ \\
\hline Post & 160 & 25.340 & 160 & $110-200$ \\
\hline
\end{tabular}

Table 2. Diastolic Blood Pressure Distribution Before And After Intradialityc Exercise and Foot Hand Massage Treatment

\begin{tabular}{lcccc}
\hline Variabel & Mean & SD & $\begin{array}{c}\text { Media } \\
\boldsymbol{n}\end{array}$ & $\begin{array}{c}\text { Min- } \\
\text { max }\end{array}$ \\
\hline pre & 99 & 15.183 & 95 & $90-150$ \\
\hline post & 91.50 & 10.400 & 90 & $70-110$ \\
\hline
\end{tabular}

Table 3. Results of Systole Statistical Test Analysis

\begin{tabular}{lccc}
\hline & $\mathrm{N}$ & $\begin{array}{c}\text { Mean } \\
\text { Rank }\end{array}$ & $\begin{array}{c}\text { Sum of } \\
\text { Ranks }\end{array}$ \\
\hline Subtraction & 15 & 8.23 & 123.50 \\
Enhancement & 1 & 12.50 & 12.50 \\
Ties & 4 & & \\
Total & 20 & & \\
P value & 0.003 & & \\
Z score & -2.953 & & \\
\hline
\end{tabular}

Table 4. Results of Diastole Statistical Test Analysis

\begin{tabular}{lllc}
\hline & $\mathrm{N}$ & $\begin{array}{l}\text { Mean } \\
\text { Rank }\end{array}$ & $\begin{array}{c}\text { Sum of } \\
\text { Ranks }\end{array}$ \\
\hline Subtraction & 10 & 6.90 & 69.00 \\
Enhancement & 2 & 4.50 & 9.00 \\
Ties & 8 & & \\
Total & 20 & & \\
P value & 0.015 & & \\
Z score & -2.437 & & \\
\hline
\end{tabular}

The results of univariate blood pressure analysis in tables 1 and 2 show the results of systolic blood pressure analysis before treatment, the median value for systolic blood pressure is $170 \mathrm{mmHg}$, with a minimum blood pressure of $150 \mathrm{mmHg}$, a maximum of 210 $\mathrm{mmHg}$, while systolic blood pressure after treatment, the median value of blood pressure is $160 \mathrm{mmHg}$ with minimum blood pressure $110 \mathrm{mmHg}$ maximum $200 \mathrm{mmHg}$. The results of univariate analysis of diastolic blood pressure before treatment obtained the median value of diastolic blood pressure of $95 \mathrm{mmHg}$, with a minimum blood pressure of $90 \mathrm{mmHg}$ and a maximum blood pressure of $150 \mathrm{mmHg}$, while for diastolic blood pressure results after treatment the median value of diastolic blood pressure was $90 \mathrm{mmHg}$, with pressure Minimum blood pressure is $70 \mathrm{mmHg}$ and maximum blood pressure is $110 \mathrm{mmHg}$.

The results of the paired group bivariate analysis for systolic blood pressure in Table 3.Based on the Wilcoxon test, it shows a significance value of $0.003(p<0.05)$, this indicates that there is a difference in systolic blood pressure between before and after the intradialytic exercise treatment and foot hand massage.

The results of the bivariate analysis of diastolic blood pressure in table 4 . Wilcoxon test, obtained data of $0.015 \quad(p<0.05)$ significance, this indicates that there is a difference in diastolic blood pressure between 
before and after the intradialytic exercise treatment and foot hand massage.

Hypertension or high blood pressure in patients with renal failure can cause damage to renal blood vessels and kidney failure usually occurs an increase in the hormones renin, angiotensin and aldosterone which stimulate an increase in blood pressure to increase (Price SA, 2002). Patients with kidney failure at an advanced stage are reported to have hypertension (Sjabani, et al, 2012)

Research conducted by (Luana et al: 2012) reports that one of the complications of hemodialysis is anxiety or anxiety, while one of the nursing actions that can be given to patients who are going to be hemodialysis is massage relaxation techniques (CAO, Callaghan, 2009), and Research conducted by (Jeong, et, al. 2018) reported that intradialytic exercise can stabilize hemodynamics in hemodialysis patients.

Based on the results of this study, the researchers assumed that the actions of intradialytic exercise and foot hand massage can make relaxation which can affect the patient's psychological calmer, more relaxed and can affect the dilation of blood vessels, relaxation can affect the release of endorphin hormones, have a positive impact on systolic blood pressure and diastole in renal failure patients undergoing hemodialysis, especially those with hypertension. Good blood pressure, systole diastole, becomes more stable. This supports the sharpening of the research conducted (Jeong, et, all 2018) which states that intradialytic exercise can stabilize hemodynamics in hemodialysis patients.

Massage is a nursing action that can support as a complement to the implementation of hemodialysis.

Conclusion and

Suggestions. Intradialytic exercise and foot hand massage have the effect of making it more stable to systolic blood pressure and diastolic blood pressure. This action can be applied to patients with kidney failure.

Acknowledgements. Thanks to the researchers say to all those who have helped in completing this research.

\section{References}

C.A.O,Callaghan, (2009). At a Glance Sistem Ginjal. Penerbit Erlangga.
Jeong,et al (2018), Effects of acute intradialytic exercise on cardiovascular responses in hemodialysis

patients:https://www.ncbi.nml.nih.gov.pubm ed.diakses 23 november 2018

Keliat, BA, (2016). Prinsip dan Praktik Keperawatan Kesehatan Jiwa Stuart, Elsevier Singapore Pte Ltd

Lee YM(2011). Effects of self-foot reflexology on stress, fatigue, skin temperature and immune response in female undergraduate student, http://www.ncbi.nlm.nih.gov/pubmed/21516 005

Mary Baradero et.al, (2009).Klien Gangguan Ginjal. EGC Jakarta

Melo et,al (2018). Musical intervention on anxiety and vital parameters of chronic renal patients: a randomized clinical trial. https://www.ncbi.nlm.nih.gov/pubmed/2953 8579

Musavian et,all (2018). Comparing the effects of active and passive intradialytic pedaling exercises on dialysis efficacy, electrolytes, hemoglobin, hematocrit, blood pressure and health-related quality of life.

https://www.ncbi.nlm.nih.gov/pubmed/2583 0161

Price.S.A (2002). Pathofisiology.Clinical Concepts Of Disease Processes, 6 edition. Mosby Year Book

Sja'bani et al ( 2012). Naskah Lengkap Simposium Peningkatan Pelayanan Hemodialisis, Penyakit Ginjal Dan Aplikasi Indonesia Renal Registry Joglosemar. Pernefri Yogyakarta

Resić H,et,al (2014), The effect of intradialytic exercise program on the quality of life and physical performance in hemodialysis patients:

https://www.ncbi.nlm.nih.gov/pubmed/2601 2142

Semaan V1, Noureddine S2, Farhood $\mathrm{L}(2018)$.Prevalence of depression and anxiety in end-stage renal disease: A survey of patients undergoing hemodialysis. https://www.ncbi.nlm.nih.gov/pubmed/3022 0369

Tchape et,all,(2018). Physiological and psychosocial stressors among hemodialysis patients in the Buea Regional Hospital, Cameroon.

https://www.ncbi.nlm.nih.gov/pubmed/3019 7740 